Check for updates

The BMJ

fgodlee@bmi.com Follow Fiona on Twitter @fgodlee

Cite this as: BMJ2020;370:m3392 http://dx.doi.org/10.1136/bmj.m3392

Published: 03 September 2020

\section{Living with covid-19}

Fiona Godlee editor in chief

"Death is not the only adverse outcome of covid-19," writes Nisreen Alwan, an epidemiologist who is experiencing a range of prolonged, fluctuating, and debilitating symptoms several months after her initial mild illness. ${ }^{1}$ Like a growing number of people around the world, she has what is being called post-acute or long covid.

While most people recover quickly and completely from the virus, stories of persistent and troubling symptoms have now moved from anecdote to the evidence of crowd sourced cohorts. Reports suggest that one in three people have not fully recovered several weeks after initial illness. A smaller but still substantial proportion have symptoms and difficulties that persist for months. These are not people who have been seriously ill in hospital, whose difficult journey to recovery is better understood. ${ }^{2}$ These are often physically fit, younger people who report persistent exercise intolerance, breathlessness and cough, ${ }^{3}$ anxiety, palpitations, and poor concentration. Paul Garner describes boom and bust-the illusion of recovery only to fall back into mental and physical exhaustion. ${ }^{4}$ These false dawns add to the burden for "long haulers," he says, which for him includes intense fatigue, mood swings, muscle and joint pains, headaches, and brain fog.

One of the most distressing aspects of living with long covid, says Garner, is the dismissive attitude of some doctors. This may change as more doctors find themselves affected. So how should doctors respond to their patients struggling with this complex and worrying multisystem disorder? Trish Greenhalgh and colleagues recommend taking a whole person, pragmatic approach with symptom management that avoids overinvestigation. ${ }^{5}$ With so much uncertainty about the cause and course of long covid, a doctor's key role is to be a witness, they say, "honouring the story' of the patient whose protracted recovery is unexpected, alarming, and does not make sense.”

The challenge for those in charge of our public health response to covid-19 is to make sense of this emergent information. Policies and messaging must now reflect the risks to younger people of developing prolonged illness and multiple organ damage, especially in light of other new information about the risks of airborne transmission. ${ }^{67}$ For this, we need to be able to quantify the risks through proper population surveillance and to mitigate them with effective systems of rapid testing, tracing, isolation, and support. ${ }^{8}$ In the UK, at least, such crucial traditional public health approaches still seem a long way off. ${ }^{9}$

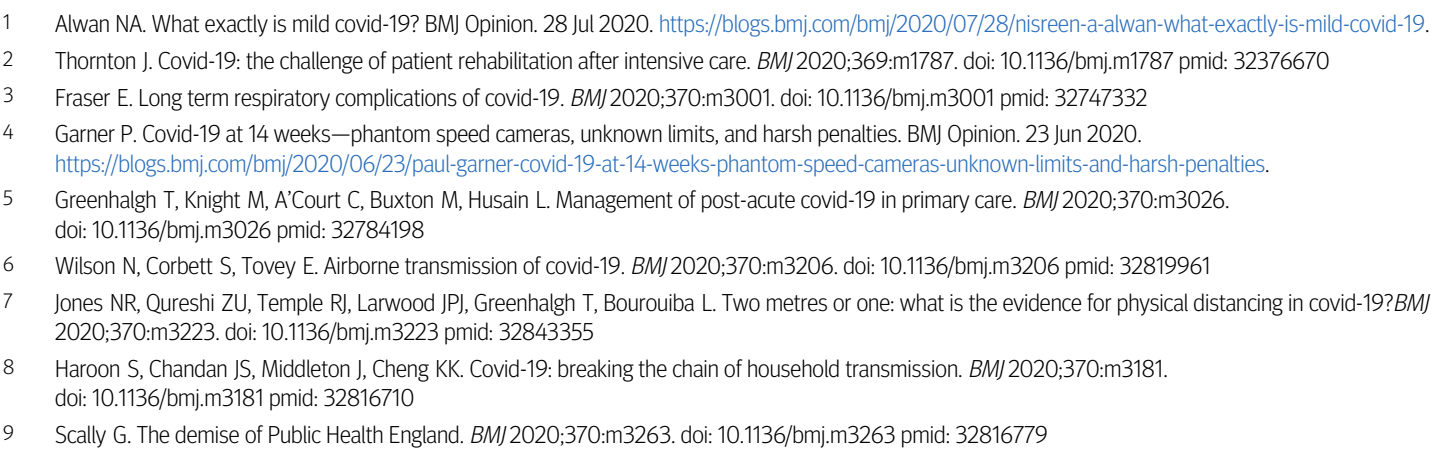

$8 \quad$ Haroon S, Chandan JS, Middleton J, Cheng KK. Covid-19: breaking the chain of household transmission. BMJ 2020;370:m3181. doi: 10.1136/bmj.m3181 pmid: 32816710

9 Scally G. The demise of Public Health England. BMJ2020;370:m3263. doi: 10.1136/bmj.m3263 pmid: 32816779

This article is made freely available for use in accordance with BMJ's website terms and conditions for the duration of the covid-19 pandemic or until otherwise determined by BMJ. You may use, download and print the article for any lawful, non-commercial purpose (including text and data mining) provided that all copyright notices and trade marks are retained. 